\title{
ANALYSIS OF THE WASTE RECYCLING PROCESS FOR NON-STRUCTURAL CONCRETE MANUFACTURING
}

\author{
Barbara Robson Luna de Oliveira ${ }^{1}$, Jéssica Luna Camico ${ }^{2}$, Jéssica Oliveira Soares ${ }^{3}$
}

\begin{abstract}
${ }^{1}$ Discente de Engenharia Civil. Centro Universitário do Norte (UNINORTE), Manaus-AM.
${ }^{2}$ Mestre em Ciências Biológicas. Instituto Nacional de Pesquisas da Amazônia (INPA), Manaus-AM.

${ }^{3}$ Mestre em Tecnologia da Informação. Centro Universitário do Norte (UNINORTE), Manaus-AM.
\end{abstract}

Email: b.luna@gmail.com, jesyka.luna@gmail.com, jessica.oliveira@uninorte.com.br

Received: June 26th, 2019

Accepted: July $31^{\text {th }}, 2019$

Published: September $30^{\text {th }}$, 2019

Copyright $@ 2016$ by authors and Institute of Technology Galileo of Amazon (ITEGAM). This work is licensed under the Creative Commons Attribution International License (CC BY 4.0). https://creativecommons.org/lice nses/by/4.0/

\begin{abstract}
One of the major challenges facing society, in order to avoid environmental degradation and the contamination of water and soil sources, is the adequate disposal of industrial and urban waste. The area of construction is also considered to be the most harmful to the environment, especially as regards the waste of natural resources and the gradual increase of waste. This study aims to analyze the waste recycling process for the manufacture of non-structural concrete, promoting the practice of waste recycling as a sustainable alternative for the disposal of the debris. In order to respond to the research objectives, the methodological choice was a bibliographical review of the integrative type. The study showed that waste recycling is a sustainable alternative for waste disposal, reducing the chances of deposition in clandestine sites, helping to relieve pressure on landfills and allowing reuse of previously discarded materials.
\end{abstract}

Keywords: Concrete, Reuse, Waste.

\section{INTRODUCTION}

The construction industry has an important socioeconomic and strategic role in the development of the country as one of the sectors that contributes most to the gross domestic product (GDP) and the great generation of jobs, the sector also includes all the complex chain of activities linked the construction, as directly and indirectly related services to the branch, suppliers of industrial inputs and other. In the first half of 2015, the construction industry accounted for $10.1 \%$ of the country's total GDP, according to data presented by the Brazilian Chamber of Construction Industry (CBIC, 2016) obtained through the surveys of the Brazilian Institute of Geography and Statistics (IBGE) industry employed more than 9 million employees in 2014, which represented approximately $8.67 \%$ of jobs for that year [1].

Civil Engineering is the most important area when it comes to structure, since it allows the development and execution of projects and constructions of buildings, roads, tunnels, subways, dams, ports, airports, choosing the most suitable places for a construction, the analysis of the solidity and safety of the site, the material to be used in the project and the monitoring of the progress of the project [2].

On the other hand, the area of civil construction is also considered to be the most harmful to the environment, mainly as regards the waste of natural resources and the gradual increase of waste.

Civil construction, which is a basic activity in any world economy, has been facing the era of cost reduction, since construction materials in several countries are being depleted and transport costs, from more distant places, are increasing.

The construction industry has been incessantly pursuing more efficient and modern construction methods and systems to increase productivity, reduce waste and meet growing demand. When choosing a construction system for a building, it is recommended that a study be carried out to understand the most suitable construction method for each situation and for the different types of construction [3].

One of the serious urban problems is the generation and disposal of solid waste from buildings and demolitions, directly reflecting the environmental quality of the urban spaces of the municipalities. 
In this scenario, waste recycling appears as a sustainable alternative and a powerful weapon for the disposal of the debris, combating the problem making the waste again usable in the construction sector itself, where there is great potential for absorption.

The recycling of waste, besides reducing the chances of deposition in clandestine places, represents lower costs and allows the reuse of previously discarded materials. The reason for the formations and accumulations of such wastes are generated by disorganized urbanization, erroneously constructed concrete buildings and natural tragedies from wars with bombardment and armed conflict [4].

Waste management, understood here as a term referring directly or indirectly to the collection, transportation, transhipment, treatment and final disposal of solid wastes and environmentally adequate tailings disposal [5], is governed by technical norms, federal laws and decrees, resolutions of the National Environment Council-CONAMA and the National Sanitary Surveillance Agency-ANVISA, among other norms [5]

The National Environmental Council (CONAMA), in the use of the powers conferred on it by Law 6.938, establishes guidelines, criteria and procedures for the management of construction waste, supporting the initiative and the use of technologies for recycling of waste, considering the need to stimulate the minimization of waste generation.

As a result, this article aims to analyze the waste recycling process for the manufacture of non-structural concrete, promoting the practice of waste recycling as a sustainable alternative for the disposal of the debris.

\section{THEORETICAL REFERENCE}

\section{II.1 FUZZY MODELING APPLIED TO WASTE MANAGEMENT}

Fuzzy logic is one of the most current technologies in the development of systems to control sophisticated and modern processes. With its use, complex requirements can be implemented in simple controllers, easy maintenance and low cost [6].

Civil construction is embedded in a complex and dynamic environment where a wide variety of factors, often unknown, are influential on the goals of organizations and projects. This environment is made even more complex by the need to associate fast and accurate responses in an extremely competitive market.

To reach this demand, tools that aid in risk management have been developed in the literature, and applied in real cases, providing solutions and being incorporated into the management model in order to assist the manager in decision making. These tools should be able to compose systems that identify and analyze these factors, allowing the decision maker to chart ways that avoid risks and promote opportunities.

In order to deal with the uncertain and incomplete data of this scenario, where natural language is also one of the most used variables in the environmental characterization, several of these studies have been incorporating fuzzy logic.

The incredible complexity and dynamism of construction projects has imposed substantial uncertainties and subjectivities in the process of risk analysis. Most problems in risk analysis contain a mix of quantitative and qualitative data. Thus, pure quantitative techniques may be inadequate. The application of a fuzzy-based methodology allows the transformation of linguistic variables and subjective judgment to deal with qualitative data. The fuzzy theory has a great adaptability to diverse environments, and has been adapted to the methods of decision making. These methods include consideration of multicriteria and alternatives, and input data in the form of linguistic variables [7].

\section{2 APPLICABILITY OF RFID IN WASTE MANAGEMENT}

The automation system can also be used in risk management works that compromise worker safety. Engineers and safety technicians are unable to coordinate all activities $100 \%$ of the time of their duration, so most of the time the application of safety standards are on the workers' own account.

In this context, it would be highly interesting to have a system to support the work of these professionals, which would guarantee automatic updating integrated to the work activities, as well as the monitoring of the development of these tasks, providing security professionals with an omniscient and semiautomatic system for construction management in real time. This monitoring can be done by installing an RFID tag on each employee's clothing, which can then be monitored through a wireless sensor system scattered throughout the site at strategic points.

It has already been proven that the use of automation in construction sites provides significant improvements in the material logistics process. A pilot logistics system was implemented in a work of Gafisa in Santos, SP, to try to solve the vertical transportation of materials in the work, which according to the coordinator was one of the bottlenecks of the work in question.

The proposed system requires the materials from this work to arrive on pallets, which are unloaded in a specific area (material dock), where the quantities are checked and a bar code is generated for each pallet containing mailing information (indicates where it will be stored - work, block and floor) [8].

This code must be read by a robust terminal (data collector) both when it is deposited and when it is withdrawn for use, so that it can be tracked at the site. The main objective is to plan the work in order to minimize the movement of materials at the construction site, as well as to concentrate the vertical transportation of materials through the rack, reducing costs with equipment rental and working hours [8].

All of these materials' worksite logistics procedures could be even more efficient with the implementation of RFID technology, which would make it possible to read pallet labels faster, even on the move, and would also ensure the real-time tracking of the pallets in the work, recording its entire trajectory.

In this pilot study of Gafisa was observed the reduction of material consumption of 5 to $20 \%$, basically due to the reduction of movement and retransportation, as well as the elimination of excess stockpiled materials, two activities that can cause damages, increasing the volume of rubble in the work. Cost savings have also been recorded, since the unloading and conferencing of the products is carried out more quickly, with an average time of 15 to 20 minutes recorded, against 5.5 hours spent by the method traditionally used in works [8].

RFID technology can be applied in numerous areas for warehouse control, material and waste tracking, entry and exit control of products, vehicles and people, identification of tools or animals, among others. RFID technology is a premise for process control and management in any industry and has the potential to save the industry [9].

In another study, the use of these construction and demolition wastes (RCD) made it possible to reduce the use of the natural resources used in this process, avoiding future shortages and reducing the amount of waste generated.

The experiments obeyed the norms in force for the use of these materials and their employabilities, since their mechanical resistance must obey the demands made by them. 
It can be verified in the experiments that the concrete resistance varied in average $4 \mathrm{Mpa}$ of the conventional concrete, being able to be used for shallow foundations of small structures. The consistency of the concrete with RCD was close to the consistency of the conventional concrete, bearing the trace had good adhesion as to its specific mass.

Due to the absorption rate being greater when compared to the commonly used gravel the concrete with the residue needed a greater addition of water than the usual concrete trait. The use of $\mathrm{RCD}$ as a bulk aggregate for concrete met the requirements regarding the standardization of its use [10].

\section{MATERIALS AND METHODS}

\section{1 DEFINITION OF CONCEPTS AND MAIN RESEARCH PARAMETERS}

The first step is to determine the basic concepts that should be explored by the research. Specifically, for the search strategy and for the accomplishment of the bibliographical research it is necessary to define the environment of contextualization, the problematic and the general objective, whose purpose is to enable the definition of the main key concepts. Context analysis, the definition of a problem and the guiding questions begin the process of scientific research, motivating the researchers to seek information about a certain subject on a bibliographic basis [11].

The objective is to fully exploit the potential of existing and available bibliographic databases and the information technology tool for the treatment of these data. As a result, the literature review article will address publications with the following parameters:

- Publications that encourage the use of technologies for the recycling of waste;

- Publications containing the non-structural concrete manufacturing process;

- Publications that disclose techniques or methods that present the benefits of waste recycling for the manufacture of non-structural concrete.

\section{III.2 RESEARCH STRATEGY DEFINITION}

Once the search knowledge area is determined, the keywords that will be used to search for references should be chosen. Thus, from these key concepts found, Boolean search logic is used to construct the keyword tree [12].

The strategy of structuring the tree aims to unfold the objectives of the research in keywords, both vertically and horizontally. In the vertical sense, the intention is to establish distinct and complementary thematic areas that allow the research to be comprehensive. In the horizontal sense, the thematic areas are subdivided into several branches, guaranteeing the depth and the specialization of the research. [3].

Using Boolean search logic, where keywords are linked to the "and" and "or" connectors, the researcher must remember that the strategy of using the connectors is very important because it explains the existence of many or few articles found. When the searcher uses the "e" in the linking of the keywords, the search action is restrictive, since the search will only find article when there are keywords connected by "and".

When the searcher uses "or" in the keyword link, the search action is opened because they find articles with at least one of the keywords linked by "or". That way, choosing the connectors and where to position them in the keyword tree is strategic. Finally, the search mechanisms are defined as the most appropriate to the research theme, according to their relevance and ease of obtaining and processing the data [13].

As a result, this article of bibliographic review was developed through scientific research of Scielo, Scopus, IEEE, Google Scholar, among others, using the keywords: "waste recycling"; "non-structural concrete"; "recycling" + "waste"; "waste recycling" and "non-structural" + "concrete".

\section{III.3 METHOD OF ANALYSIS OF RESULTS}

The method of analysis of results was delineated according to the flowchart of figure 1:



Figure 1 - Flow of the process of obtaining and analyzing the results.

Source: Authors, (2019).

In the first stage of the study, a filter was carried out among the researched articles whose most relevant parameter was the focus of the study: waste recycling and non-structural concrete manufacturing. If the articles met this criterion and were published within 10 years, they would soon be analyzed and quoted in this article.

\section{III.4 TYPE OF RESEARCH}

In order to respond to the research objectives, the methodological choice was a bibliographical review of the integrative type. The integrative bibliographic review emerged as an alternative to rigorously review and combine studies with different methodologies. It has the potential to promote review studies in several areas of knowledge, maintaining the methodological rigor of systematic reviews [15].

The integrative review method allows the combination of data from the empirical and theoretical literature that can be directed to the definition of concepts, identification of gaps in the areas of studies, review of theories and methodological analysis of the studies on a certain theme 7 .

The combination of research with different methods combined in the integrative review extends the possibilities of literature analysis.

\section{RESULTS AND DISCUSSIONS}

Construction Aggregates are materials with random shape and volume holders of suitable dimensions and properties for the preparation of concrete and mortar in civil construction. They have a relatively low cost and this is one reason for their use. The 
aggregates with constant employment in construction are sand and gravel.

Through the recycling of concrete it is possible to obtain aggregates with characteristics similar to the original product. The contribution to the environment is great because it stops extracting natural resources, thus reducing the environmental impact.

With the rapid growth of civil construction, waste disposal has become a heinous problem, causing significant environmental impacts, since many of these materials are destined for clnadestine landfill, as can be seen in Figure 2:

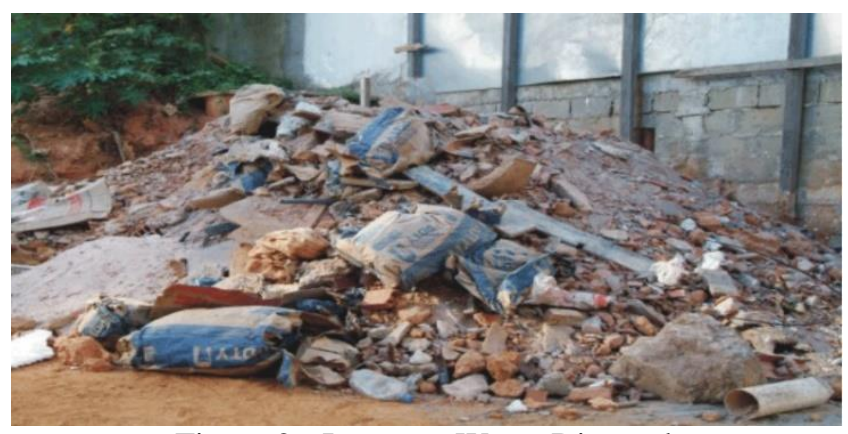

Figure 2 - Incorrect Waste Disposal. Source: [15].

\section{IV.1 APPLICABILITY}

\section{IV.1.1 PAVING}

One of the ways to use construction and demolition waste (DRC) is to substitute, in the paving of urban roads, the layers of natural materials, such as the graded stone, by decidedly DRC.

For this layer substitution process to have validity and feasibility, it is indispensable the structural evaluation of the pavements constructed, by means of a survey of defletometric measurements with the Benkelman beam. The calibration of this equipment and the correct procedure of the test method are of fundamental importance for the collection with adequate precision of the deflections in the pavements.

The applicability of the residues in the paving requires less use of technology, allows the use of all the mineral components of the debris, energy saving in the process of grinding of the debris, greater efficiency of the residue when added to the soils and saprolíticos in relation to the same addition made with as can be seen in figure 3 :

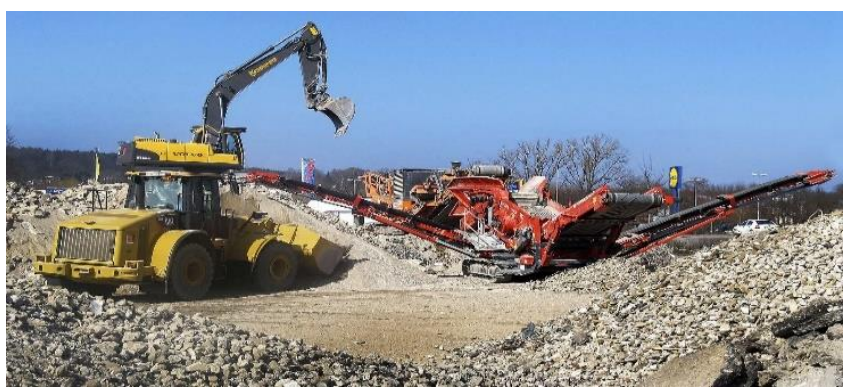

Figure 3 - Applicability of the residues in the paving [12]. Source: Authors, (2019).

\section{IV.1.2 AGGREGATED FOR NON-STRUCTURAL CONCRETE}

The main characteristics of the residues and aggregates for concrete technology are: granulometry, water absorption, particle shape and texture, compressive strength and modulus of elasticity.
The knowledge of these characteristics is a requirement for the composition of the concrete traces, after all the granulometry, the porosity or the specific mass, the shape and the texture determine the properties of the concretes in the fresh state.

The porosity and the mineralogical composition affect the compressive strength, the hardness and the modulus of elasticity, influencing in numerous properties of the concrete in the hardened state, as can be seen in figure 4 :

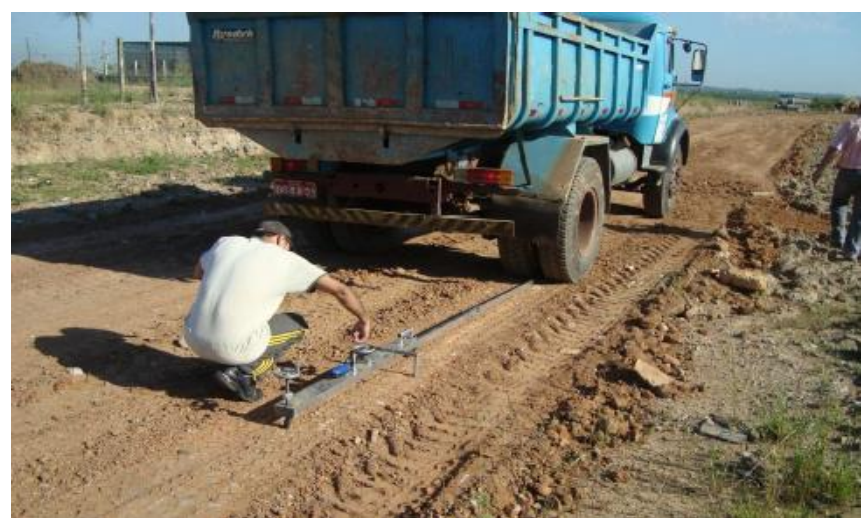

Figure 4 - Aggregate for non-structural concrete. Source: Authors, (2019).

Among the natural aggregates and recycled aggregates, it can be noted that the main differences are the lower specific mass value, higher value of water absorption rate and a certain amount of mortar adhered to the surfaces of the particles of the recycled aggregate. This directly influences the properties of the concretes produced with the AGR, in the fresh state and in the hardened state [16].

\section{IV.1.3 AGGREGATE FOR ARGAMASSA CONFECTION}

The recycled aggregates generally present physical characteristics different from those of the natural aggregates, which directly affects the performance of the mortars. However, partial substitutions of the natural aggregates by the recycled ones have performed satisfactorily.

In addition, other advantages of this applicabilide are that they can be processed by equipment called mortars, can be used of the residue at the generator site, which eliminates transport costs, has the pozzolanic effect presented by the crushed waste, contributes with the reduction in the consumption of the cement, of the lime and presents a gain in the compressive strength of the mortars, which can be seen in figure 5:

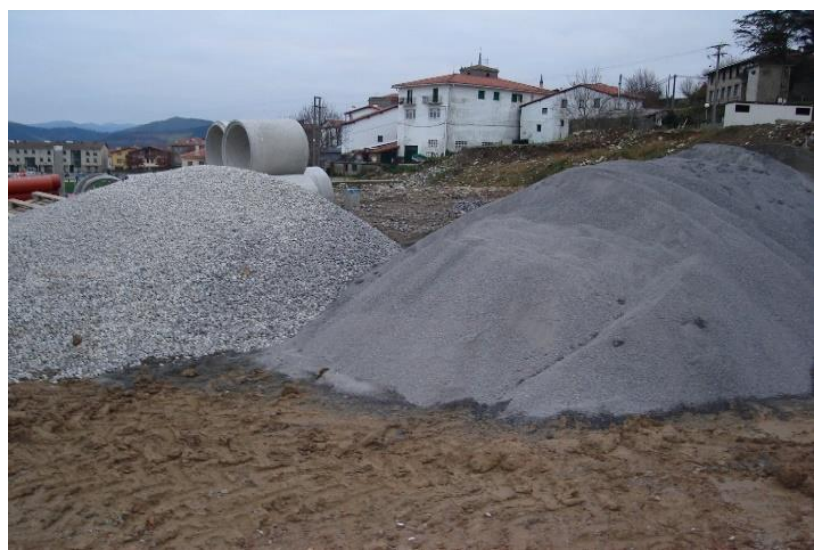

Figure 5 - Aggregate for the preparation of mortar. Source: Authors, (2019). 


\section{IV.1. 4 OTHER APPLICABILITIES}

Residues can still be applied in the massive recycling of fly ash and basic blast furnace slag, calcination of clays and addition of limestone filler, 29\% reduction in $\mathrm{CO}_{2}$ generation and $28 \%$ fuel economy.

Another intresting applicability of waste is in road scrapping, void filling in buildings, installation trenches, and landfill reinforcement.

In the literature it is common to observe the use of residues to obtain the active silica, used in addition or partial replacement to the cement, in the concrete production, presenting higher compressive strength, lower porosity, higher resistance to abrasion and chemical corrosion, to other concrete surfaces, better adherence with steel and void filling effect between cement particles ("filer effect").

Steel scrap is another possibility for waste recycling, which is intended for the reinforcement of reinforced concrete, representing an economy in 1997 of around 6 million tons of iron ore, avoiding the generation of around 2.3 million tons of waste and 11 million tonnes of $\mathrm{CO}_{2}$ [17].

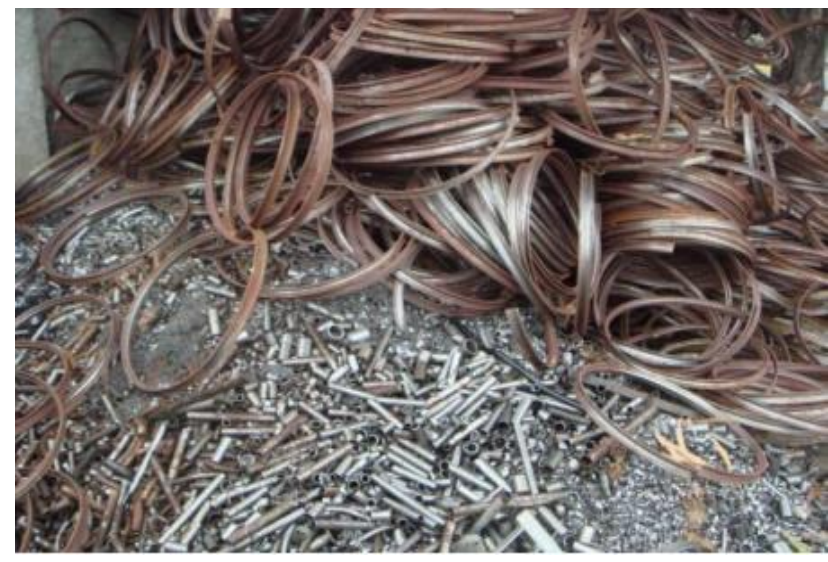

Figure 6 - Scrap recycled through an electric arc. Source: Authors, (2019).

\section{CONCLUSION}

The bibliographic analysis of the waste disposal processes in the civil works resulted in the understanding of the tests, permeability and abrasion, performed with debris prepared for nonstructural concrete, corresponding satisfactorily with the requirements of the manufacture of pieces of concrete for be used in surface drainage of roads, where there is no movement of vehicles, such as gutters, construction of guides and blocks of pavement.

According to the litetatura study, in the event of a control of debris transported to the recycling plants, so that the material with different characteristics does not mix, before passing through the crusher, this material will obtain an aggregate superiority.

In addition to attesting all these factors, the research collaborated indirectly with the improvements related to the environment, demonstrating the alternative of using debris as an aggregate for the production of non-structural concrete.

This practice provides for the use of material provided by the waste recycling plants, which enables increased production, and as a result, the decrease of illegal deposits of construction waste.

Thus, the debris can be used in the fabrication of constructive elements, making the formation and maintenance of the urban infrastructure (gutters, guides and pavement blocks), as a more economical method, besides contributing to the increase of the quality of life of society.

It is recommended to build recycling centers in the city and municipalities, providing economic advantages, reducing the number of courses with transportation, number of buckets, besides making feasible the use of waste due to the large supply and decrease the daily volume deposited in the landfills.

The study also showed that waste recycling is a sustainable alternative for disposal of debris, drastically reducing the chances of deposition in clandestine sites, helping to relieve pressure on landfills and allowing the reuse of previously discarded materials.

\section{THANKS}

To the Galileo Institute of Technology and Education of the Amazon (ITEGAM) and to the University Center of the North (UNINORTE), for the support to the research.

\section{REFERENCES}

[1] Olimpio, M. C. Luiz. Modelo Fuzzy para Análise de Riscos em projetos de Edificações. 2017. Disponível em: $<$ http://repositorio.ufc.br/ bitstream/riu

fc/28716/3/2017_tcc_lcmolimpio.pdf>. Acessado em 15 Jun 2019.

[2] Junior, V. V. D.; Ferreira, A. E.; Oliveira, S. C. J. Comparative Analysis for Viability of Paving Between Rubber and Conventional Asphalt. Journal of Engineering and Technology for Industrial Applications, vol. 5, Ed. 18, 2019.

[3] Farias, S. A.; Brito, C. R.; Alencar, D. B.; Reis, M. H. N.; Junior. J. A. B.; Sanches, A. E. Feasibility of using the light steel frame system in civil construction works in the city of Manaus-Amazonas. Journal of Engineering and Technology for Industrial Applications, vol. 4, ed. 16, 2018.

[4] Leite, M. B. Avaliação de propriedades mecânicas de concretos produzidos com agregados reciclados de resíduos de construção e demolição. Programa de Pós-graduação em Engenharia Civil. Universidade Federal do Rio Grande do Sul. Porto Alegre, 2001. Disponível em: http://www.lume.ufrgs.

br/handle/10183/21839 acesso em 20/03/2019.

[5] Brasil. Subchefia para Assuntos Jurídicos. Lei $N^{\circ} 12.305$, de 2 de agosto de 2010 que institui a Política Nacional de Resíduos Sólidos; altera a Lei no 9.605, de 12 de fevereiro de 1998 e dá outras providências. Brasília: Casa Civil, 2010.

[6] Klir, J. G.; Floger, A. T. Fuzzy Sets, Uncertainty, and Informations. Prentice Hall, Englewood Cliffs - New Jersey, 1988.

[7] Zavadska, E. K. et al. Integrated group fuzzy multi-criteria model: Case of facilities management strategy selection. Expert Systems with Applications, v. 82, p. 317-331, 2017.

[8] Tamaki, L. Canteiro com códigos de barras. Revista Téchne, n.163, outubro de 2010 .

[9] Oliveira, S. C. J.; Nascimento, R. H. M.; Junior, B. A. J.; Freitas, O. A. C. RFID System Applicability Model for Traceability of Luggage at Airports. International Journal of Advanced Engineering Research and Science, 5(8), pp.120-127. 
[10] Santos, M. P.; Jimenez, T. J. I.; Brito, R. C. Analysis of mechanical performance in concrete using as raw material waste of construction and demolition. Journal of Engineering and Technology for Industrial Applications. Vol. 4, Ed. 16, 2018.

[11] Tasca, J. E. et al. An approach for selecting a theoretical framework for the evaluation of training programs. Journal of European Industrial Training, v. 34, n. 7, p. 631-655,2010. Available <http://dx.doi.org/10.1108/03090591011070761>.Accessed in 25/04/2019.

[12] Jusbrasil. No Brasil, $80 \%$ das estradas não são asfaltadas. 2015. Available in <https://folhapolitica. jusbrasil.com.br/noticias/135832618/no-brasil-80-das-estradasnao-sao-asfaltadas>. Accessed in 20/04/2019.

[13] Treintaa, F. T.; Filho, J. R. F.; Sant'Annac, A. P.; Rabelod, L. M. Metodologia de pesquisa bibliográfica com a utilização de método multicritério de apoio à decisão. Available in <http://www.scielo.br/pdf/prod/2013nahead/aop_prod0312.pdf>. Accessed in 09/05/19.143.

[14] Lacerda, R. T. O.; Ensslin, L.; Ensslin, S. R. Uma análise bibliométrica da literatura sobre estratégia e avaliação de desempenho. Gestão \& Produção, v. 19, n. 1, p. 59-78, 2012. Available in: <http://dx.doi.org/10.1590/S0104530X2012000100005>. Accessed in 21/04/2019.

[15] Silva, G. ACWEB - Reciclagem de resíduos é alternativa sustentável para destinação de entulhos. Disponível em: $<$ https://www.aecweb.com.br/cont/m/rev/reciclagem-de-residuose-alternativa-sustentavel-pa ra-destinacao-deentulhos_7628_10_20>. acessao em 15 Mai 2019

[16] Buttler, M. A. Concreto com agregados graúdos reciclados de concreto - influência da idade de reciclagem nas propriedades dos agregados e concretos reciclados. Dissertação (Mestrado) - Escola de Engenharia se São Carlos. Universidade de São Paulo, São Carlos. 2003.

[17] UFMG. Utilização de resíduos na construção civil. Disponível em:

$<$ http://www.demc.ufmg.br/tec3/residuos\%20na\%20constru\%E7a o\%20civil.pdf $>$. Acessado em 15 Mai 2019. 